\title{
STRATEGI PEMBELAJARAN BAHASA INGGRIS YANG MENYENANGKAN UNTUK ANAK USIA DINI
}

\author{
${ }^{1}$ Farida Samad / ${ }^{2}$ Nurlela Tidore \\ ${ }^{1)}$ Dosen PG-Paud/, ${ }^{2}$ Mahasiswa, FKIP, Universitas Khairun
}

\begin{abstract}
Early childhood have a sensitive period to learn something, especially learning English. As an English teacher, it is very important to know learning strategy in order to make learning environment more pleasant. That is why the teachers who teach English for young children need some strategies in teaching and learning. There are some strategies that can be applied such as TPR (total physical responsed, songs, music and movement, and stories.
\end{abstract}

\section{PENDAHULUAN}

Anak-anak memiliki keampuan berpikir yang masih fresh. Dimana mereka mengalami suatu periode yang dinamakan masa keemasananak usia dini yang begitu peka atau sensitive untuk mendapat rangsangan dari luar. Suyanto (2005: 6) mengatakan bahwa pada masa keemasan anak mengalami pertumbuhan dan perkembangan yang sangat pesat dan tidak tergantikan pada masa mendatang.Menurut berbagai penelitian di bidang neurologi terbukti bahwa 50\% kecerdasan anak terbentuk dalam kurun waktu 4 tahun pertama. Setelah anak berusia 8 tahun perkembangan otaknya mencapai $80 \%$ dan pada usia 18 tahun mencapai $100 \%$. (Atri, 2012)

Anak-anak juga memperoleh pelajaran dari pengalaman yang menarik.Mereka senang dengan suatu permainan yang bersifat menyenangkan.Sebagaimana yang dicantumkan dalam buku Hamid (2012:18-19) bahwa bermain dengan suasana menyenangkan merupakan faktor sangat penting dalam pendidikan. Huizinga (1955) menyatakan bahwa bermain dan bersenang-senang merupakan aktivitas yang esensial bagi semua manusia. Dalam psikologi positif para teoritikus, seperti Csiszentmihalyi (1998) menjelaskan dalam teori alir (flow teory) bahwa umat manusia itu bisa melaksanakan apapun dengan cara yang terbaik, jika mereka mampu terlibat secara total dalam aktivitas yang menyenangkan.

Untuk itulah mendesain strategi pembelajaran yang menyenangkan untuk anak usia dini merupakan sesuatu tugas yang wajib untuk pengajar atau guru yang mengarah pada pembelajaran anak usia dini. Yang di maksud dengan strategi pembelajaran adalah suatu rencana yang dilakukan oleh pengajar pada anak didiknya untuk mencapai tujuan belajar mengajar yang efektif.Dalam hal ini pendidik atau guru harus mampu mengelola suatu kegiatan belajar mengajar agar mampu menciptakan interaksi pembelajaran yang baik terhadap peserta didik. Adapun defenisi strategi pembelajaran menurut Suparman (1997:157) adalah perpaduan dari urutan kegiatan, cara mengorganisasikan materi pelajaran peserta didik, peralatan dan bahan, dan waktu 
yang digunakan dalam proses pembelajaran untuk mencapai tujuan pembelajaran yang telah ditentukan. (Dedi, 2012)

Disisi lain strategi pembelajaran membutuhkan kreatifitas pengajar untuk mengatur semua persiapan pembelajaran, guna mencapai tujuan belajar mengajar yang mendorong motivasi peserta didik untuk semangat dengan pelajaran yang diberikan. Seperti halnya pada pelajaran bahasa Inggris untuk anak usia dini, yang mana pengajar harus mempunyai kemampuan untuk mengubah suasana pembelajaran yang tadinya jenuh menjadi lebih menyenangkan. Sehingga mereka lebih mudah memperoleh pengetahuan yang diberikan. Dewasa ini, diketahui bahwa banyak guru atau pengajar bahasa Inggris yang bisa mengajar dikalangan dewasa yang bersifat serius namun kehilangan cara untuk menimbulkan suasana kelas yang menyenangkan untuk mengajarkan pelajaran Bahasa Inggris kepada anak usia dini, dan juga memanfaatkan kognitif mereka yang terus berkembang.dengan mempelajari bahasa Asing khususnya bahasa Inggris yang menyenangkan bagi anak usia dini. Oleh karena itu, penulis mengangkat judul tentang "Strategi Pembelajaran Bahasa Inggris yang Menyenangkan untuk Anak Usia Dini"sehingga pembaca dapat memanfaatkan kognitif anak yang berkembang pesat dan mengaplikasikannya dalam pengajaran bahasa Inggris yang baik dan menyenangkan untuk mereka.

\section{KAJIAN PUSTAKA}

\section{a. Perencanaan Pembelajaran}

Pembelajaran berasal dari kata dasar "belajar" yang berarti sebuah proses, cara, perbuatan sehingga orang atau siswa belajar dan memperoleh ilmu pengetahuan. Jadi kata pembelajaran adalah suatu proses belajar mengajar (PBM) yang merupakan keterpaduan antar kegiatan guru sebagai pengajar dan kegiatan siswa sebagai pelajar sehingga terjadi saling interaksi keduanya dalam situasi instruksional yang bersifat pengajaran (Widiputera, 2004). Secara definisi, perencanaan merupakan keseluruhan proses pemikiran dan penentuan semua aktivitas yang akan dilakukan pada masa yang akan datang dalam rangka mencapai tujuan. (Prabowo dan Nurmaliyah, 2010:1)

Perencanaan pembelajaran adalah upaya dalam proses belajar mengajar yang dipikirkan serta ditentukan pada suatu pembelajaran berikutnya sehingga dapat menimbulkan suatu interaksi yang baik dan peserta didik dapat memperoleh pengetahuan maupun ilmu yang diajarkan. Yang sejalan dengan konsep tersebut Prabowo dan Nurmaliyah (2010:2) bahwa penerapan kegiatan perencanaan dalam kegiatan pembelajaran merupakan suatu upaya untuk menentukan berbagai kegiatan yang akan dilakukan dalam kaitan dengan upaya untuk mencapai tujuan dari proses pembelajaran tersebut.

b. Bahasa Inggris Anak Usia Dini, dan Perkembangan Kognitif

Sesuai dengan Undang-undang Sisdiknas tahun 2003 pasal 1 ayat 14, upaya pembinaan yang ditujukan bagi anak usia 0-6 tahun tersebut dilakukan melalui Pendidikan anak usia dini (PAUD). Pendidikan anak usia dini dapat dilaksanakan melalui pendidikan formal, nonformal dan informal. Pendidikan anak usia dini jalur 
formal berbentuk taman kanak-kanak (TK) dan Raudatul Athfal (RA) dan bentuk lain yang sederajat. Pendidikan anak usia dini jalur nonformal berbentuk kelompok bermain (KB), taman penitipan anak (TPA), sedangkan PAUD pada jalur pendidikan informal berbentuk pendidikan keluarga atau pendidikan yang diselenggarakan lingkungan seperti bina keluarga balita dan posyandu yang terintegrasi PAUD atau yang kita kenal dengan satuan PAUD sejenis (SPS). (Atri, 2012)

Kedudukan Bahasa Inggris di Indonesia merupakan bahasa asing pertama (the first foreign language).Kedudukan tersebut berbeda dengan bahasa kedua.Mustafa (2007) dalam hal ini menyatakan bahwa bahasa kedua adalah bahasa yang dipelajari anak setelah bahasa ibunya dengan ciri bahasa tersebut digunakan dalam lingkungan masyarakat sekitar. Sedangkan bahasa asing adalah bahasa negara lain yang tidak digunakan secara umum dalam interaksi sosial. Kedudukan bahasa Inggris di Indonesia tersebut mengakibatkan jarang digunakannya bahasa Inggris dalam interaksi sosial di lingkungan masyarakat sehingga bahasa Inggris merupakan bahasa yang sulit untuk dipelajari karena bahasa Inggris merupakan bahasa asing yang tidak digunakan seharihari dalam kehidupan masyarakat di Indonesia. (Khairani 2009)

Faktanya, penguasaan bahasa Inggris adalah keterampilan yang sangat penting dalam era informasi dan komunikasi saat ini.Hal ini sangat menentukan bagaimana kita dapat berinteraksi secara global.Isu globalisasi saat ini menuntut sumberdaya manusia yang berkualitas dan mampu berkomunikasi dalam berbagai bahasa asing terutama bahasa Inggris sebagai bahasa internasional.Keahlian berbahasa asing ini diperlukan untuk menguasai ilmu pengetahuan, memiliki pergaulan luas dan karir yang baik. Hal ini membuat semua orang dari berbagai kalangan termotivasi untuk mengusai bahasa Inggris. Kecenderungan masyarakat akan penguasaan bahasa asing tersebut, membuat mereka saling berlomba memasukkan anak-anak mereka untuk mempelajari bahasa Inggris sebagai salah satu keahlian yang dikembangkan.Hal ini berdasarkan asumsi bahwa anak lebih cepat belajar bahasa asing dari pada orang dewasa (Santrock, 2007:313). Sebuah penelitian yang dilakukan Johnson dan Newport, 1991 (Santrock, 2007:313) menunjukan bahwa imigran asal Cina dan Korea yang mulai tinggal di Amerika pada usia 3 sampai 7 tahun kemampuan bahasa Inggrisnya lebih baik dari pada anak yang lebih tua atau orang dewasa. Penelitian lain yang menyatakan kebermanfaatan menguasai bahasa asing lebih dini, dinyatakan Mustafa (2007), bahwa anak yang menguasai bahasa asing memiliki kelebihan dalam hal intelektual yang fleksibel, keterampilan akademik, berbahasa dan sosial. Selain itu, anak akan memiliki kesiapan memasuki suatu konteks pergaulan dengan berbagai bahasa dan budaya. Sehingga ketika dewasa anak akan menjadi sumber daya manusia yang berkualitas dan bisa berprestasi. Mustafa (2007) menambahkan bahwa pemahaman dan apresiasi anak terhadap bahasa dan budayanya sendiri juga akan berkembang jika anak mempelajari bahasa asing sejak dini.(Khairani 2009)

Perkembangan kognitif menggambarkan bagaimana pikiran anak berkembang dan berfungsi sehingga dapat berpikir (Mansur, 2005: 33). Keat menyatakan bahwa perkembangan kognitif merupakan proses mental yang mencakup pemahaman tentang dunia, penemuan pengetahuan, pembuatan perbandingan, berfikir dan mengerti 
(Purwanti dan Widodo, 2005: 40). Proses mental yang dimaksud adalah proses pengolahan informasi yang menjangkau kegiatan kognisi, intelegensi, belajar, pemecahan masalah dan pembentukan konsep. Hal ini juga menjangkau kreativitas, imajinasi dan ingatan. (Atri, 2012)

\section{c. Strategi - strategi Pembelajaran Bahasa Inggris yang Menyenangkan untuk Anak Usia Dini}

\section{Metode TPR (Total Physical Response Method)}

Menurut Richards TPR didefinisikan "a language teaching method built around the coordination of speech and action; it attempts to teach language through physical (motor) activity".Jadi metode TPR (Total Physical Response) merupakan suatu metode pembelajaran bahasa yang disusun pada koordinasi perintah (command), ucapan (speech) dan gerak (action); dan berusaha untuk mengajarkan bahasa melalui aktivitas fisik (motor). Sedangkan menurut Larsen dan Diane dalam Technique and Principles in Language Teaching, TPR atau disebut juga "the comprehension approach" atau pendekatan pemahaman yaitu suatu metode pendekatan bahasa asing dengan instruksi atau perintah.(Widiputera, 2004)

Dikembangkan oleh James Asher, seorang profesor psikologi Universitas Negeri San Jose California. Metode yang sesuai untuk mengajarkan bahasa Inggris pada anak usia dini dimana pembelajarannya lebih mengutamakan kegiatan langsung berhubungan dengan kegiatan fisik (physical) dan gerakan (movement). Dalam metode TPR ini, Asher mengatakan bahwa semakin sering atau semakin intensif memori seseorang diberikan stimulasi maka semakin kuat asosiasi memori berhubungan dan semakin mudah untuk mengingat (recalling).Kegiatan mengingat ini dilakukan secara verbal dengan aktifitas gerak (motor activity). Nurul (2014)

Lebih lanjut, Asher yang juga menyimpulkan bahwa peran faktor emosi sangat efektif dalam pembelajaran bahasa anak, artinya belajar bahasa dengan melibatkan permainan dengan bergerak yang bisa dikombinasikan dengan bernyanyi atau bercerita akan dapat mengurangi tekanan belajar bahasa seseorang. Dia percaya bahwa dengan keceriaan dalam diri anak (positive mood) akan memberikan dampak yang baik bagi belajar bahasa anak. Nurul (2014) .Contoh kegiatan dengan metode tersebut :

Contoh pembelajaran dengan metode ini adalah sebagai berikut: ketika mengenalkan kata stand up (berdiri) semua anak ikut berdiri sambil mendengarkan (listening) kata stand up dan mengucapkan (speaking) kata stand up tersebut. Disini kita tidak perlu menekankan pada pengenalan bahasa tulis (written language)walaupun kita bisa sekali-sekali menuliskan kata tersebut tapi tidak menjadi keharusan.Kemudian kita bisa menguatkan pengenalan kata tersebut sambil bernyanyi dan sambil bergerak sesuai perintah lagu. (Nurul ,2014)

Every body sit down, sit down, sit down

Every body sit down just like me

Every body stand up, stand up, stand up

Every body stand up, just like me 


\section{Teaching English by using song}

Pembelajaran bahasa Inggris dengan menggunakan lagu adalah salah satu metode atau cara mengajarkan bahasa inggris dengan menggunakan nyanyi atau lagu sebagai media nya (Nurul, 2014). Mengingat bahasa Inggris merupakan bahasa asing di Indonesia, tentunya proses pembelajarannya memerlukan pendekatan yang tepat dan efektif. Keberhasilan pembelajaran bahasa Inggris pada anak usia dini sangat dipengaruhi oleh kemampuan seorang guru dalam menyajikan proses kegiatan belajar mengajar yang menarik dan menyenangkan bagi anak. Sejalan dengan keberadaan seorang anak yang senang menyanyi dan bergerak maka gerak dan lagu adalah salah satu pendekatan yang sangat tepat jika digunakan sebagai sarana dalam menyajikan proses pembelajaran bahasa Inggris pada anak usia dini. Menyajikan proses pembelajaran yang menarik dan menyenangkan bagi anak dengan tidak meninggalkan kaidah berbahasa Inggris yang baik dan benar. (Widiputera, 2004)

Musik dapat memperkaya kehidupan rohani dan memberikan keseimbangan hidup bagi anak.Melalui musik, manusia dapat mengungkapkan pikiran dan perasaan hatinya serta dapat mengendalikan aspek emosionalnya.Adapun nyanyian adalah bagian dari musik.Nyanyian berfungsi sebagai alat untuk mencurahkan pikiran dan perasaan untuk berkomunikasi. Pada hakikatnya nyanyian bagi anak-anak adalah sebagai: (Widiputera, 2004)

1. Bahasa Emosi, dimana dengan nyanyian anak dapat mengukapkanperasaannya, rasa senang, lucu, kagum, haru.

2. Bahasa Nada, karena nyanyian dapat didengar, dapat dinyanyikan, dandikomunikasikan.

3. Bahasa Gerak, gerak pada nyanyian tergambar pada birama (gerak/ ketukan yang teratur), pada irama (gerak/ketukan panjang pendek, tidak teratur), dan pada melodi (gerakan tinggi rendah).

Lebih lanjut Alfaridi (2006) menjelaskan berdasarkan pengalaman para guru bahasa Inggris dan menurut para ahli bahasa seperti yang dinyatakan oleh Abdulrahman Al-Faridi lagu-lagu berbahasa Inggris dapat membantu para guru untuk menciptakan pembelajaran yang aktif, kreatif dan menyenangkan (Nurul, 2014). Nyanyian dan musik digunakan sebagai teknik dalam proses pembelajaran bahasa Inggris. Musik yang memiliki berbagai kandungan elemen di dalamnya dapat dijadikan salah satu bentuk fasilitas untuk mengembangkan kemampuan kognitif anak.Tinggi nada memberikan kesempatan kepada anak untuk melatih kepekaan pendengarannya.Perubahan-perubahan ritme atau irama musik melatih anak untuk membedakan irama internal (inner rhythm) serta kemampuan motoriknya (misalnya, jika dikombinasikan dengan latihan gerak sesuai dengan liriknya) (Nurul, 2014).

Keuntungan mengajarkan bahasa Inggris menggunakan nyanyian:

1. Melalui lagu akan memotivasi anak untuk lebih senang mempelajari bahasa Inggris.

2. Dengan menyanyi anak menjadi senang dan lebih mudah dalam memahami materi ajar yang disampaikan. Kemampuan guru dalam memilih lagu dan 
menciptakan gerakan yang sesuai dengan usia perkembangan anak akan berdampak pula terhadap berhasilnya proses pembelajaran bahasa Inggris pada anak usia dini.

3. Melalui nyanyian dan kegiatan pembelajaran yang bervariasi, pendidik dapat menumbuhkan minat anak untuk lebih senang dan giat belajar, bahkan dapat memudahkan anak dalam memahami materi ajar yang disampaikan.

4. Anak dibuat senang, tidak bosan, dan tertarik dalam mengikuti proses pembelajaran.

Dengan demikian bernyanyi merupakan suatu kegiatan yang sangat disukai oleh anak-anak.Secara umum menyanyi bagi anak lebih berfungsi sebagai aktivitas bermain dari pada aktivitas pembelajaran atau penyampaian pesan.Menyanyi dapat memberikan kepuasan, kegembiraan, dan kebahagiaan bagi anak sehingga dapat mendorong anak untuk belajar lebih giat (Joyful Learning). Dengan nyanyian seorang anak akan lebih cepat mempelajari, menguasai, dan mempraktikkan suatu materi ajar yang disampaikan oleh pendidik. Selain itu kemampuan anak dalam mendengar (listening), bernyanyi (singing), berkreativitas (creative) dapat dilatih melalui kegiatan ini.

\section{Teaching english by using games}

Widiputera (2004) menjelaskan dalam pembelajaran Bahasa Inggris banyak metode dan teknik yang dapat digunakan, diantaranya melalui:

a. Story Telling (Bercerita)

b. Role Play (Bermain Peran)

c. Art and Crafts (Seni dan Kerajinan Tangan)

d. Games (Permainan),

e. Show and Tell,

f. Music and Movement (Gerak dan Lagu) dimana termasuk di dalamnya singing (Nyanyian)

Teaching english by using games: Pembelajaran bahasa inggris dengan menggunakan game (permainan sebagai media nya).

Keuntungan menggunakan games dalam pembelajaran:

- Penyampaian materi pelajaran dapat diseragamkan

Dengan menggunakan media game dalam kegiatan belajar, maka akan ada penyeragaman penafsiran dari guru mata pelajaran terhadap mata pelajaran yang akan disampaikan kepada para siswa.

- Proses pembelajaran menjadi lebih menarik

Media game terdiri dari unsur visual (dapat dilihat), audio (dapat didengar) dan gerak (dapat berinteraksi). Jadi media game ini dapat membangkitkan keingintahuan siswa, merangsang reaksi mereka terhadap penjelasan guru, memungkinkan siswa 
menyentuh objek kajian pelajaran, membantu mereka mengkonkretkan sesuatu yang abstrak dan sebagainya.

- Proses belajar siswa menjadi lebih interaktif

Adanya unsur Al (artificial Intelligence) atau kecerdasan buatan pada media game, maka akan terjadi komunikasi dua arah dimana pertanyaan muncul secara acak pada layar komputer dan siswa menjawab pertanyaan tersebut. Dengan semakin tingginya pemrograman komputer pada Al, maka game yang dibuat dapat semakin komplek disesuaikan dengan tingkat kemampuan dari siswa itu sendiri. Contohnya adalah game simulasi.

- Jumlah waktu belajar mengajar dapat dikurangi

Dengan media game, maka guru tidak perlu menghabiskan waktu banyak untuk menjelaskan materi. Dengan media game, siswa dapat melatih dirinya dengan cara berinteraksi dengan media game mengenai suatu materi yang mereka ingin pelajari.

- Kualitas belajar siswa dapat ditingkatkan

Selain lebih efisien dalam proses belajar-mengajar seperti diuraikan diatas, media game dapat membantu siswa menyerap materi pelajaran secara lebih mendalam dan utuh. Hal ini disebabkan media game lebih menarik karena ada unsur visual dan audio tetapi juga interaktif yang membuat siswa bisa ber-interaksi dengan program game tentang suatu mata pelajaran. Contohnya adalah quiz game.

- Proses belajar dapat terjadi dimana saja dan kapan saja

Perkembangan teknologi yang semakin pesat, memungkinkan siswa saat ini dapat memiliki laptop dengan harga yang murah.Perangkat ini mempunyai kelebihan dapat dibawa kemana - mana dan dapat digunakan kapan saja. Media game biasanya berbentuk CD interaktif yang dapat dipergunakan kapan saja. Sehingga media game sebagai media pembelajaran dapat dipergunakan kapan saja dan dimana saja.

- Sikap positif siswa terhadap bahan pelajaran maupun terhadap proses belajar itu sendiri dapat ditingkatkan

Dengan media, proses belajar mengajar menjadi lebih menarik. Hal ini dapat meningkatkan kecintaan dan apresiasi siswa terhadap ilmu pengetahuan dan proses pencarian ilmu itu sendiri.

- Peran guru dapat berubah ke arah yang lebih positif dan produktif

Pertama, guru tidak perlu mengulang-ulang penjelasan mereka bila media digunakan dalam pembelajaran. Kedua, dengan mengurangi uraian verbal (lisan), guru dapat memberi perhatian lebih banyak kepada aspek - aspek lain dalam pembelajaran. Ketiga, peran guru tidak lagi sekedar "pengajar", tetapi juga konsultan, penasihat, atau manajer pembelajaran.

\section{Teaching english by using stories}

Belajar bahasa Inggris dapat dilakukan dengan berbagai cara, salah satunya adalah dengan membaca cerita pendek berbahasa Inggris. Dengan membaca kalimat perkalimat bahasa inggris tetapi yang masih mudah dipahami akan sangat membantu 
kita dalam memahami cerita berbahasa inggris tersebut. Langkah langkah penerapan belajar bahasa inggris dengan bercerita adalah sebagai berikut:

a. Siapkan media, alat peraga serta bila perlu seorang guru harus hafal cerita nya terlebih dahulu.

b. Ciptakan suasana yang menyenangkan, nyaman dan membuat anak penasaran dengan cerita yang akan kita bacakan.

c. Sebelum bercerita, buat perjanjian dengan anak. Jangan ada yang bertanya sebelum ibu menyelesaikan cerita. kalau ada anak anak ibu yang ingin bertanya harap ditunda dulu ya.

d. Nah bacakan cerita dengan penuh semangat dan semenarik mungkin setelah selesai membacakan cerita mintalah anak mengulangi apa yang kita ceritakan lalu jika ada yang bertanya dipersilahkan.

\section{Langkah-langkah Pembelajaran Kosakata Bahasa Inggris anak dengan Menggunakan Metode Gerak dan Lagu.}

Keberhasilan proses pembelajaran Bahasa Inggris pada anak usia dini tentunya dipengaruhi oleh banyak faktor, antara lain: 1) Guru yang berkualitas, guru yang dapat menghidupkan proses kegiatan belajar mengajar. 2) Sumber dan fasilitas pembelajaran yang memadai dan memenuhi syarat. 3) Kurikulum yang baik, sederhana, dan menarik (atraktif). Karena pada hakekatnya music (musik) adalah seni menyusun nada atau suara dalam urutan, kombinasi, dan hubungan temporal untuk menghasilkan komposisi yang mempunyai kesatuan dan kesinambungan (mengandung irama).Dan ragam nada atau suara yang berirama disebut juga dengan lagu. Jadi musik ataupun lagu merupakan satu kesatuan yang tidak dapat dipisahkan dan dapat digunakan sebagai sarana dalam sebuah proses pembelajaran. Sedangkan movement yang berarti gerakan, berasal dari kata dasar gerak.Dan 'gerak' memiliki makna, suatu peralihan tempat (adanya aktifitas) yang dilakukan setelah ada dorongan (batin/perasaan).Aktifitas gerakan dapat timbul setelah seseorang mendengarkan lagu/nyanyian.Maka pemanfaatan gerak dan lagu dalam pembelajaran dapat dilakukan sebagai berikut (Pulukadang\& Laiya).

\section{a. Ketika Baru Masuk Kelas}

Untuk mendapatkan atensi anak sebelum memulai pembelajaran, anak diajak untuk dapat duduk baik dengan hati yang senang (tidak dalam keadaan terpaksa). Hal ini dilakukan dengan mengajak anak menyanyikan lagu sambil menggerakkan anggota badan. Misalnya dengan menyanyikan lagu "Sit Together" (Tune: Where Is Thumbkin?) Sit together, sit together, look at me, look at me, how are you today, how are you today, look at me, look at me. Nyanyian (lagu) ini dapat dinyanyikan dengan posisi anak duduk membentuk lingkaran di lantai, dan bernyanyi dengan gerakan menepuk paha masingmasing. Guru sebagai model haruslah dapat menghidupkan suasana kelas agar anak merasa nyaman dengan lagu dan gerakan yang dinyanyikan bersama. Melalui nyanyian ini anak diharapkan dapat memahami makna dari lagu yang mereka nyanyikan.

\section{b. Sebagai Pembuka (Doa dan Salam)}


Setiap proses belajar hendaknya diperkenalkan juga kepada anak untuk berdoa dan saling mengucapkan salam. Melalui kegiatan berdoa pendidik dapat mengenalkan dan membina anak agar selalu dekat kepada Tuhan. Sebelum maupun sesudah melakukan aktivitas anak dapat diajak

menyanyikan lagu doa, misalnya: lagu “Morning Prayer" sebelum melakukan kegiatan. Thank you God.For helping us to come to our school. Now we are going to study Please bless us Thank you God, Amien. Artinya: Terima kasih Allah. Karena telah membantu kami untuk datang kesekolah Sekarang kami akan pulang Mohon berkahi kami Terima kasih Allah, Amin. Nyanyian ini hendaknya dilakukan dengan posisi anak berdoa.Mengajak anak untuk saling Nyanyian ini hendaknya dilakukan dengan posisi anak berdoa. Mengajak anak untuk saling menyapa dengan baik dapat dilakukan dengan menyanyikan, misalnya: lagu "Hello-hello" Hello,hello, hello and how are you? I'm fine, l'm fine, I hope that you are too.

Ketika lagu ini dinyanyikan, anak diajak untuk saling melambaikan tangannya sebagai gerakan menyapa. Mengucapkan salam dalam bahasa Inggris (greeting), dapat juga dikenalkan melalui yanyian, misalnya: lagu "Good Morning". Good morning, my friends, Good morning teachers How are you today? Very well, I thank you. Nyanyiannyanyian tersebut hendaknya dapat dinyanyikan pada setiap proses pembelajaran berlangsung, karena pengulangan (repetition) sangat diperlukan bagi anak usia dini dalam mempelajari hal yang baru.

\section{c. Sebagai Apersepsi}

Sebagai pengantar pembelajaran suatu materi ajar, guru dapat menggunakan nyanyian sebagai appersepsinya. Contoh: Ketika mengajar dengan tema 'wajahku', guru dapat mengajak anak menyanyi antara lain: lagu "Parts of Body" (Tune: Head and Shoulders) My Eyes, my ears, my mouth my nose, 2x My hand, my foot, my neck, My Eyes, my ears, my mouth my nose, We are clapt hands together. Demikian juga ketika mengajarkan tema-tema ajar lainnya, seperti tema 'transportasi' dapat juga menggunakan lagu misalnya, "The Train", untuk tema 'binatang' banyak nyanyian yang bisa digunakan, antara lain, "Baba black sheep", "Little lion". Tema tentang keluarga "I love you my family", tema makanan dapat juga diperkenalkan misalnya melalui lagu "Good food", dll.Masih banyak nyanyian (lagu) anak-anak yang dapat dinyanyikan untuk appersepsi ini. Hal penting yang perlu diperhatikan adalah, nyanyian yang dipilih haruslah sesuai dengan materi ajar yang akan disampaikan dan tingkat perkembangan kejiwaan anak.

\section{d. Dalam Pembelajaran Inti}

Pada saat kegiatan belajar mengajar berjalan, guru dapat menyelingi dengan nyanyian, bahkan dalam pembelajaran salah satu aspek bahasa itu sendiri, seperti pelafalan atau pengucapan, nyanyian dapat digunakan sebagai materi ajar. Contoh: Untuk mengajarkan bunyi dari suatu huruf (phonics sound), misalnya kita dapat belajar sambil bernyanyi "Letters Sounds"

\section{ABCDEFGHIJKLMNOPQRSTUVWXYZ}


Ketika anak menyanyikan lagu ini, guru dapat sambil menunjukan kartu huruf yang dimaksud.Sehingga diharapkan anak dapat memahami bentuk hurufnya secara visual dan melafalkan bunyinyadengan baik dan benar. Contoh lain dapat dicari dari berbagai sumber yang sudah ada, atau juga diciptakan oleh guru sendiri dengan mempertimbangkan kesesuaian antara situasi dan kondisi sertamateri yang akan disampaikan. Nyanyian sebagai materi ajar, di dalam pembelajarannya tidak hanya dinyanyikan tetapi jugadibaca dan dipahami oleh anak. Karenanya materi nyanyian harus disesuaikan dengan usia anak, agar menyanyi menjadi sesuatu kegiatan yang menyenangkan bukan menjadikan beban.

\section{Sebagai Penutup Kegiatan Belajar Mengajar}

Setelah menyelesaikan proses pembelajaran anak diajak untuk merapikan semua perlengkapannya sambil bernyanyi, misalnya dengan lagu "Clean Up Time". Clean up time! Clean up time! Everything will look just fine, We'll pick up the things and put them all away, We can use another day. Melalui kegiatan ini anak dapat dilatih untuk mandiri dan mengembangkan rasa tanggung jawab mereka. Untuk mengakhiri proses pembelajaran nyanyian dapat juga digunakan sebagai salam penutup, misalnya lagu (tune: lagu Sayonara):

My friends it's time to go home It's time to rest, it's time to go home Good bye my friends $2 X$ Till we meet again Good bye my friends. Akhirnya anak akan diajak untuk doa pulang secara bersama-sama, dengan lirik: Thank you God. For helping us to come to our school.

Now we are going to home Please bless us Thank you God, Amien. Artinya: Terima kasih Allah.. Karena telah membantu kami untuk datang kesekolah Sekarang kami akan pulang Mohon berkahi kami Terima kasih Allah, Amin. Hal ini merupakan langkah-langkah pembelajaran kosakata bahasa Inggris anak usia dini yang baik dengan menggunakan metode gerak dan lagu.

\section{KESIMPULAN}

Anak usia dini mempunyai periode yang sensitive atau peka terhadap sesuatu. Segala macam aspek dalam berbahasa bisa diperkenalkan kepada mereka sebelum masa ini berakhir, Karena setelah anak berusia 8 tahun perkembangan otaknya mencapai $80 \%$. Oleh karena itu, pengajar atau guru harus berusaha berikan yang terbaik untuk memanfaatkan masa anak usia dini dengan memberikan strategi-strategi yang mampu mendongkrak semangat dan motivasi dengan apa yang diberikan, khususnya untuk pengajaran bahasa Inggris. Seperti yang diketahui bahwa anak-anak menyukai sesuatu yang bersifat menyenangkan. Untuk itulah dalam pembelajaran bahasa Inggris dapat diterapkan tentang strategi pembelajaran anak usia dini yang 
menyenangkan melalui Metode TPR (Total Physical Response Method), stories, dan songs sehingga mempermudah mereka menyukai pembelajaran bahasa Inggris

\section{REFERENSI}

Sugeng, Listyo Prabowo dan Farida Nurmaliyaj.2010.Perencanan Pembelajaran. Malang: UIN-Maliki Press

Moh. Sholeh Hamid. 2012. Metode Edutainment. Jogjakarta: Diva Press

Atri. 2012. Kajian Teori http://eprints.uny.ac.id/9706/2/Bab\%202\%20\%2009111247004.pdf (online), (http://digilib.unimed.ac.id/public/UNIMEDArticle-23390- e\%20irma\%20khairani.pdf.html, diakses 6 Februari 2014

Dedi. 2012. Pengertian Strategi Pembelajaran. (online), (http://digilib.unimed.ac.id/public/UNIMED-Article-23390e\%20irma\%20khairani.pdf, diakses 15 Februari 2014)

Ade Irma Khairani. Pendidikan Bahasa Inggris untuk Anak Usia Dini. (online) http://digilib.unimed.ac.id/public/UNIMED-Article-23390\%20irma\%20khairani.pdfdiakses 9 Februari 2014)

Ferdi Widiputera. 2004. Model - Model Pembelajaran Bahasa Inggris Yang Inovatif Untuk Anak Usia Dini (online) http://sippendidikan.org/file upload/04.Penelitian\%20Pengembangan\%20Model \%20Pembelajaran\%20Inovatif\%20By\%20Ferdi.pdf diakses 9 Februari 2014)

Wiwy T. Pulukadang dan Sri Wahyuningsih Laiya.Meningkatkan Pengenalan Kosakata Bahasa Inggris Melalui Metode Gerak dan Lagu pada Anak Kelompok B Di Tk Pembina Kecamatan Kota Kota Gorontalo.http://ejurnal.fip.ung.ac.id/index.php/PDG/article/viewFile/164/159 